\title{
Actorness and effectiveness in international disaster relief: The European Union and United States in comparative perspective
}

International Relations 27(3) 356-374

(C) The Author(s) 2013

Reprints and permissions: sagepub.co.uk/journalsPermissions.nav DOI: I0.1 I77/0047| I 78|3497298 ire.sagepub.com

@SAGE

\section{Erik Brattberg}

Swedish Institute of International Affairs

\section{Mark Rhinard}

Stockholm University and Swedish Institute of International Affairs

\begin{abstract}
This article examines the role of the European Union (EU) and United States as actors in international disaster relief. We take the analysis of 'actorness' one step further than normal by assessing the extent to which different aspects of EU and US actorness led to effectiveness in actual outcomes. In doing so, we make two contributions. First, we provide a rare comparison between EU and US foreign policy actorness, shedding light on the actor capability of each bloc in the area of international disaster relief. Second, we specify the relationship between actorness and effectiveness, a relationship which is too often assumed rather than explored. Using previous research of EU and US actorness as a starting point, we link four aspects of actorness to effectiveness and assess the resulting hypotheses using the case of the 2010 Haiti earthquake. We find support for our proposed links between actorness and effectiveness, although further research is needed before robust conclusions can be drawn.
\end{abstract}

\section{Keywords}

actorness, cooperation, disaster response, effectiveness, European Union, foreign policy, humanitarian assistance, United States

\section{Corresponding author:}

Mark Rhinard, Stockholm University, Stockholm SE-106 9I Stockholm, Sweden.

Email: mark.rhinard@ekohist.su.se 


\section{Introduction}

International disaster response is a high-profile focus for many states around the world and a major component of foreign policy in both the European Union (EU) and United States. ${ }^{1}$ Indeed, as two powerful economic and foreign policy actors with public support for humanitarian relief and two-thirds of the world's humanitarian assistance resources, the EU and United States play leading roles in what might be called an international disaster relief regime. ${ }^{2}$ Participants in that regime meet regularly in institutionalised fora such as the United Nations, are guided by (mainly informal) rules regarding interaction and are called upon to act in disaster situations. ${ }^{3}$ At the same time, both the EU and United States have been the target of criticism regarding their roles in international disaster relief. During recent emergencies, the EU, although increasingly speaking and spending as a 'single voice' in humanitarian crises, has been seen as slow and incoherent in its overall approach to disasters. The United States, although typically quicker to deploy help internationally, has been criticised for poor internal coordination and inadequate civil-military cooperation. ${ }^{4}$

The ambitions of the EU and United States to play a leading role in international disaster relief, combined with apparent obstacles to such efforts, demand further investigation into each polity's 'actorness' and effectiveness. This article uses the concept of actorness to unpack the empirical features most relevant to determining the extent to which either side has 'the capacity to behave actively and deliberately' in international affairs. ${ }^{5}$ The actorness concept was first developed in an EU context, but can be applied elsewhere and is constituted by variables that, in principle, are 'abstract from any particular institutional form'. ${ }^{6}$ Thus, as the EU continues to evolve as a foreign policy entity, a comparison with the United States can offer useful insights regarding the capacities required to participate actively and deliberately in international disaster response.

We carry the analytical framework one step further. The 'actorness' concept has traditionally been a heuristic device, offering a useful characterisation of a polity's potential to impact international affairs. Divorced from the concept is the link with effectiveness in shaping outcomes. In lieu of theorising this link, analysts typically equate 'more actorness' with 'more effectiveness', rather than stipulating how actorness may lead to different kinds of effectiveness (which can then be empirically verified). This article seeks to link actorness more meaningfully to effectiveness using insights from the literature on international cooperation and from studies on international disaster relief. ${ }^{7}$ We derive preliminary hypotheses regarding how different actorness variables may relate to effectiveness in influencing international relief outcomes. Since actorness is expected to have real-life impact, we examine the January 2010 Haiti earthquake in an empirical analysis of EU and US capacities to behave actively and deliberately - as well as effectively - in international disaster relief. The Haiti earthquake provides an intriguing case since the EU and United States each declared a role for itself and public expectations rose accordingly. ${ }^{8}$

The article proceeds in the following steps. In the section 'Actorness in international disaster relief', we briefly review debates on actorness and outline previous research on EU and US efforts to act in international disaster relief. In section 'Does actorness lead to effectiveness? Some hypotheses', we link actorness to effectiveness by drawing upon 
literature related to international disaster relief and, in the course of doing so, derive preliminary hypotheses as part of this article's conceptual framework. The analytical sections of the article begin with the section 'Analysis: effectiveness in international disaster relief', which examines whether various aspects of EU and US actorness influenced effectiveness on the ground in the case of the 2010 Haiti earthquake. The conclusion draws together findings and encourages further research on several points.

\section{Actorness in international disaster relief}

The actorness concept evolved as a way to conceptualise the EU's role in world affairs without relying on traditional indicators based on statehood and rationality. Since the 1970 s, scholars have grappled with the fact that the concept of an 'international actor' is historically wedded to the concepts of the state, nation and realpolitik - and thus poorly suited to make sense of the EU's unique character and forms of influence in the world. ${ }^{9}$ The result was 'an oasis for theoretical dispute and occasional obfuscation' ${ }^{10}$ that has attracted scholarly attention ever since. Two main frameworks have emerged for assessing actorness, each using a series of variables measured in either mainly positivistic ${ }^{11}$ or interpretivist ${ }^{12}$ ways, respectively. For instance, Jupille and Caporaso argue that the EU's actorness comprises recognition, authority, cohesion and autonomy, ${ }^{13}$ while Bretherton and Vogler examine the variables of opportunity, presence and capability. ${ }^{14}$ More recent studies have criticised and qualified these two frameworks, with some arguing for greater precision in variable specification ${ }^{15}$ and others arguing for more attention to the subtle, inter-subjective processes that construct the EU's influence on the global stage. ${ }^{16}$

In previous work, the present authors studied EU actorness using a synthetic framework drawing on the above-mentioned literature while adding the category of 'consistency'. ${ }^{17}$ Too many actorness studies focus only on variables internal to the EU's institutional architecture and applicable mainly in the context of the EU's role in global negotiations. While such perspectives on actorness are important, what is missing is a measure of whether EU member states and EU institutional actors are consistent in carrying out what has been previously agreed (in laymen's terms, do they 'walk the talk' of their collective agreements) both in international settings and in field operations. Study of the EU's general 'coherence' cannot capture this measure, a considerable problem as we move towards studying effectiveness of EU global action in situ and not simply actorness as measured in Brussels (a discussion we begin in the next section). The same insight applies to the United States, considering its potential difficulties in ensuring that decisions made in Washington (and intentions formulated by the federal government) are consistently carried out in humanitarian operations in the field. ${ }^{18}$

Our previous study of the EU and United States in international disaster relief, therefore, studied actorness as measured by context, coherence, capability and consistency. ${ }^{19}$ These categories represented a drawing together of previous analytical frameworks with further development of the consistency component. The study applied the framework to evaluate actorness in the area of international disaster relief generally, and did not touch upon the question of effectiveness per se. This article takes up that challenge by linking actorness variables to effectiveness. The actorness variables used previously include the following: 
Context aspects of actorness indicate whether an entity is a recognised actor by counterparts in the international system, and whether that entity is viewed as a legitimate 'player' in formal and informal terms by both its own constituent members (in the case of the EU) and by the external entities. Our study revealed, perhaps unsurprisingly, that both the EU and United States scored highly in context-related actorness, owing to widely held perceptions and formal agreements facilitating their participation in international disaster relief.

Coherence aspects of actorness ask whether the entity can aggregate values, preferences, institutional procedures and policies in its efforts to project influence as a global actor. The previous study found that the EU enjoys considerable value and preference cohesion but falls short in institutional and policy coherence. The United States, interestingly, fared only slightly better, since it too faces challenges in ensuring inter-agency coordination and policy coherence.

Capability variables include the availability of instruments, mechanisms and other resources, and the ability to mobilise these towards policy goals. Our analysis of EU actorness in this category revealed considerable resources but some difficulties in mobilising them towards a practical disaster. For instance, EU humanitarian aid resources can be quickly approved but are more slowly dispersed owing to complex funding procedures. The United States scored quite high on capability-related actorness questions, not least because of its considerable resources and presidential authority in foreign affairs matters.

Consistency variables ask whether the entity can carry out agreed policies in practice, highlighting the capacity of various federal departments and agencies (in the case of the United States) and Brussels institutions and member states (in the case of the EU) to follow through with common positions made 'back home'. Our study showed that both the EU and United States suffered from coordination obstacles in Brussels and Washington, which can carry over to problems in the field. Space constraints in the previous study prevented deeper analysis of this aspect and an assessment of whether these four variables were somehow related.

Our previous study of actorness thus shed light not only on the cases of EU and US actorness in international disaster relief, from a comparative perspective, but also demonstrates some value in using four basic categories to gain a rich perspective on actorness more generally.

However, research on actorness has reached a crossroad at which a focus primarily, if not solely, on measuring actorness is increasingly criticised. ${ }^{20}$ Attention is turning towards gauging effectiveness of the EU as an international actor in terms of goal attainment and/or outcome effects. In line with that turn, and although the research agenda on this question is still in its infancy, the remaining part of this article attempts to forge a closer conceptual link between actorness and effectiveness.

\section{Does actorness lead to effectiveness? Some hypotheses}

Actorness approaches take us some way towards characterising a polity's potential to wield influence in international affairs. Such approaches, however, have been criticised 
for not taking the next 'logical analytical step': to theorise the link between actorness and effectiveness. ${ }^{21}$ Effectiveness is defined herein - in line with this special issue - as goal attainment $^{22}$ and relates to a polity's ability to translate potential influence into actual effect. The relationship between the two concepts remains under-specified and systematic empirical analyses of EU effectiveness are still relatively rare. ${ }^{23}$ The challenge is arriving at theoretically informed hypotheses regarding the link between different aspects of actorness and practical effects on outcomes.

This section derives some plausible hypotheses regarding how the different variables associated with actorness may contribute to effectiveness in influencing disaster relief outcomes. Although the hypotheses and indicators of effectiveness derived here relate to a specific issue-context (as advised by many scholars; see the introduction to this special issue), they should also prove useful when establishing general categories and indicators of effectiveness. In light of the complexities involved, we should note that these hypotheses are probabilistic rather than deterministic.

To begin, we ask how 'context'-related variables might relate to actor effectiveness. Regarding recognition, one might surmise that an actor widely recognised as a 'player' in a certain issue area or in a particular activity by both the international community and the recipients of disaster relief would find it easier to initiate contact with other actors (to signal intentions, for example, or to begin communication). Such a situation jump-starts coordination processes and enables lower transaction costs in those processes. ${ }^{24}$ Contrast this with a state or entity not widely recognised as a legitimate participant of a certain activity: considerable effort and energy must be expended on convincing partners (and, in the case of disasters, the affected country) of one's relevance, significance and aptitude. High degrees of recognition, opportunity and authority, we can deduce, allows an actor to 'hit the ground running', facilitating coordination with both aid partners and local actors while accelerating the delivery of mutual assistance upon arrival. Moreover, a widely recognised (and accepted) actor in disaster relief is more likely to be able to set the pace of response and to establish certain norms about how disaster relief should take place. ${ }^{25}$ We might expect that a polity displaying high levels of context-related actorness is likely to be (a) quickly accepted in situations requiring disaster relief, thus leading to (b) quick mobilisation, (c) smooth coordination and (d) strong normative influence.

Next, we consider how 'coherence' aspects of actorness relate to effectiveness. When an actor's values, preferences, procedures and policies align, several facilitators of effectiveness might follow. One is that an actor can send a clearer, more coherent message regarding its goals in a problem situation and the means it will use to achieve ends. This clarity signals a sense of purpose to a host nation and allows partners to adjust and adapt accordingly during disaster relief. ${ }^{26}$ Within the governance structures of a particular actor, a high degree of preference coherence enables constituent parts (say, the US State Department and US Department of Defense) to adjust their own behaviour in ways that are mutually complementing rather than competitive. On the ground, actor coherence in value terms facilitates a sense of purpose, while actor coherence in procedural terms allows for more effective and effortless coordination. Coherence within a polity also implies clearer leadership hierarchies, making authoritative decisions in the field easier to come by. ${ }^{27}$ Pre-identified leadership hierarchies, achieved through agreement among different institutional actors, are likely to facilitate decision-making and reduce intra-state 
conflicts during disaster relief. We might surmise that a polity with high levels of coherence-related actorness is likely to have lower transaction costs related to (a) coordination, both internally and in a host country during a disaster owing to clarity of purpose, (b) low inter-organisational competition and (c) uncontested leadership hierarchies.

We now consider how 'capability'-related variables might lead to actor effectiveness. Capability reflects whether a polity has the practical means to pursue policy goals. This includes not just the possession of relevant instruments and practical resources but also the capability to deploy them. We might expect that actor capability leads to effectiveness in fairly obvious ways. When called upon, a polity without the required resources to devote to a situation is not likely to influence outcomes significantly. This is particularly clear in situations of disaster relief, when the United States and EU would need to have access to the necessary and required resources if they are to add value to relief efforts. States providing, or arriving with, insufficient, redundant or irrelevant aid is a common problem in international disaster relief. ${ }^{28}$ Furthermore, high degrees of 'capability'related actorness should lead to more effectiveness because instruments can be put into effect, and resources mobilised, under conditions of time pressure - meaning that the required resources reach the hands in which they are most needed. ${ }^{29}$ We might then say that a polity with high levels of capability-related actorness is more likely to mobilise (a) a sufficient amount of resources which are (b) relevant to a certain disaster, thus alleviating suffering in a reasonably swift manner.

Finally, we ask how 'consistency'-related variables may lead to actor effectiveness in shaping outcomes. Consistency concerns the ability of an actor to follow through with previous policy decisions, or less prosaically, to 'stick to the line' of agreements. This is particularly apropos to the EU, where different EU institutions may work at cross-purposes and where member states may contradict EU agreements in pursuing their individual agendas. It may also apply to the United States in terms of different government agencies (and arguably even different state-based agencies and non-governmental charities) working in line with federal government priorities. High levels of consistency enable a polity's constituent states or agencies to work efficiently in the field, since previous agreements need not be 'reopened for negotiation' at every decision point. ${ }^{30}$ There is likely to be less duplication of effort, and a high likelihood that different units of a polity are working towards their own particular strengths, if an actor displays high levels of internal consistency. We would expect that a polity displaying high levels of consistencyrelated actorness will have a higher impact on outcomes through (a) agencies working together smoothly (with fewer disputes) and (b) operating in areas of relative strength (rather than in competing over operational priorities). The actorness variables, and their hypothesised link to effectiveness, are summarised in Table 1 below.

\section{Analysis: effectiveness in international disaster relief}

The EU and the United States both, to varying degrees, display attributes of 'actorness', with the United States being the more complete actor but still suffering from coherence problems. Such problems, it could be said, limit the United States' ability to act in a concerted effort and maximise the impact of its humanitarian activities. The EU scores rather highly on context, and to a lesser extent capabilities, but suffers from coherence 
Table I. Hypothesised links between actorness and effectiveness.

\begin{tabular}{ll}
\hline Actorness category & Hypothesised impact on effectiveness \\
\hline $\begin{array}{l}\text { High levels of context-related } \\
\text { actorness should lead to: }\end{array}$ & $\begin{array}{l}\text { An actor being (a) quickly accepted in situations requirin } \\
\text { disaster relief, thus enabling (b) quick mobilisation, (c) } \\
\text { smooth coordination and (d) strong normative influence }\end{array}$ \\
$\begin{array}{l}\text { High levels of coherence-related } \\
\text { Lower transaction costs related to (a) coordination, } \\
\text { both internally and in a host country during a disaster } \\
\text { owing to clarity of purpose, (b) low inter-organisational } \\
\text { competition and (c) uncontested leadership hierarchies. }\end{array}$ \\
$\begin{array}{l}\text { High levels of capability-related } \\
\text { actorness should lead to: }\end{array}$ & $\begin{array}{l}\text { (b) which are also relevant to a certain disaster, thus } \\
\text { alleviating suffering in a swifter manner. }\end{array}$ \\
High levels of consistency-related & (a) agencies working together smoothly (with fewer \\
actorness should lead to: & $\begin{array}{l}\text { disputes) and (b) operating in areas of relative strength } \\
\text { (rather than in competing over operational priorities). }\end{array}$
\end{tabular}

and consistency problems. However, the actual limitations on effectiveness which may flow from these varying attributes of actorness are not made clear by previous research. ${ }^{31}$ To delve deeper into the relationship between actorness and effectiveness, and to evaluate the hypotheses derived in the previous section, we now draw upon evidence from the international community's response to a major earthquake disaster in Haiti in January $2010 .{ }^{32}$

\section{EU}

Context-related effectiveness: quick recognition and acceptance of EU role? The EU appears to have engaged directly with the international community, including the United Nations and non-governmental organisations (NGOs), when the Haiti disaster struck. The United Nations sent out a 'flash' appeal to international donors to assist in the situation in Haiti, with a special emphasis on encouraging European governments and the European Commission to contribute. The United Nations directed specific requests to the EU to provide engineering expertise and equipment for opening routes to facilitate aid, including maritime logistic capability. Per the United Nations' request, the EU also helped reinforce the police capability of MINUSTAH, the UN Mission in Haiti (further detailed below). Some EU member states sent personnel to support the UN Disaster Assessment and Coordination (UNDAC) teams on the ground. On top of the resources provided by member states, the EU mobilised its funding mechanisms for humanitarian assistance. Regarding recognition from local actors in Haiti, it can be noted here that Europe's ties with Haiti are limited, notwithstanding France's historical relationship and (often controversial) involvement in the country's affairs. ${ }^{33}$ This fact, along with the near-total destruction of Haiti's governance capacity, explains why the EU's recognition and acceptance on the ground was not as smooth as might have been expected. Many Haitians were reportedly ambivalent about France's intervention during the crisis. ${ }^{34}$ But, in general, the urgent appeal for international assistance from the Haitian government 
suggests that the component European response would be welcomed. In sum, the EU's high level of context-related actorness served it well within the international community, although to a lesser extent among the local population, as it responded to the disaster.

Coherence-related effectiveness: low transaction costs and clear leadership? In response to the earthquake, the Council of Ministers (Foreign Affairs) set a principled tone by declaring 'the importance of the need for a rapid, coordinated response based on the humanitarian principles and to consider actions required in the course of next weeks and months'.35 Coordination problems in practice, however, were complicated by the ratification of the Lisbon Treaty in December 2009 (just 1 month before the Haiti earthquake). The new position of High Representative/Vice President (HR/VP), with organisational responsibility for the European External Action Service (EEAS) and responsibility for coordinating EU foreign policy, had just been installed in the position. Few established routines meant a reversion to Commission routines and helps to explain why the then-Commissioner for Development and Humanitarian Aid, Karel de Gucht, took the lead (with the initial blessing of the new HR/VP, Catherine Ashton). The Commissioner responsible for International Cooperation, Disaster Relief and Crisis Response (a new portfolio in 2010) had not yet been in place when the Haiti earthquake took place. The apparent lack of procedural coordination led to significant criticism, ${ }^{36}$ which under the circumstances may have been somewhat unfair and based on inflated expectations after approval of the Lisbon Treaty.

One clear problem, however, was public communication regarding response leadership, affecting transaction costs and inhibiting a clear sense of leadership. ${ }^{37}$ This problem was exacerbated by the lack of proper EU representation on the ground. Few regular briefings were made, leading to confusion as to who was in charge and what the EU's role was. It should be noted that the Council Secretariat sent evaluation teams to Haiti, independently of Commission and EEAS activities. ${ }^{38}$ In the weeks after the incident, Ashton sought to regain leadership over the Haiti response. She convened an extraordinary session of the Council of Ministers on 18 January 2010, 1 week after the earthquake (meeting as Development ministers, however, showing how the disaster cycle had moved from response to development by that point), and eventually visited the disaster site in March 2010. In sum, the long-standing lack of procedural coherence led to significant internal transaction costs in the aftermath of the disaster and confusion among the international community regarding the EU response. This was the case despite the vaunted coherence of the EU's values on humanitarian aid. The Lisbon Treaty reforms, which aim to correct some of these problems, had yet to be implemented at the time of the disaster.

Capability-related effectiveness: efficient mobilisation of the necessary resources? The EU response to the Haiti earthquake consisted initially of a few search and response teams dispatched and some $€ 300$ million allocated in immediate relief. During the initial phase of the earthquake response, EU member states offered a range of additional assets to support the Haitian government and MINUSTAH, including a military police protection team from the United Kingdom; two logistic ships with amphibious landing capability, two military building installations with medical facilities and 109 police officers from France; and an aircraft carrier with on-board hospital, an engineering task force, six 
helicopters and force protection elements (plus one military police team and one scuba diver team) from Italy. ${ }^{39}$ Additionally, some EU member states sent personnel to support the UNDAC teams on the ground. While some member state response teams arrived at the scene very quickly - some European teams were even among the first international teams to reach Haiti - others took several days to mobilise key resources. In total, EU member states made available over 2000 troops. $^{40}$

On top of the resources provided by the member states, the EU mobilised its funding mechanisms for humanitarian assistance. On 14 January 2010, the European Commission, through Directorate-General Humanitarian Aid and Civil Protection department of the European Commission (DG ECHO), provided $€ 3$ million in fast-track funds for immediate relief (the maximum amount the EU can allocate within 24 hours of an emergency). This funding was used to meet basic needs, including shelter and medical assistance, and was channelled through international relief organisations. Within a week, the amount of Commission funding for humanitarian assistance climbed to $€ 30$ million, making the total EU support $€ 122$ million, including member states' contributions. At the international donors conference in New York on 31 March 2010, the EU pledged over $€ 1.2$ billion as a part of a long-term reconstruction strategy for the country. ${ }^{41}$

In addition to financial assistance, the EU activated the Civil Protection Mechanism allowing the Commission to coordinate member states' assistance to Haiti. ${ }^{42}$ A total of 24 European countries (including non-EU-members Norway and Iceland) provided assistance through the Mechanism. The civil protection assistance provided by the member states included search and rescue teams, medical teams and supplies, shelter structures and water sanitation equipment. At least 800 EU experts were deployed to Haiti through the Mechanism. At the United Nations' request, the EU decided on 25 January to dispatch 323 paramilitary police forces from France, Italy and Spain, mainly as part of the European Gendarmerie Force (EGF), ${ }^{43}$ to assist MINUSTAH. ${ }^{44}$ There was even discussion, at one point, of launching a Common Security and Defence Policy (CSDP) military crisis management mission. However, no agreement could be found between the member states on the need for an EU military response. ${ }^{45}$ Thus, in terms of capability-based actorness, the EU undertook a variety of tasks focused on deploying material resources to the disaster site. Moreover, the EU endeavoured to match capabilities with actual needs on the ground. The apparently respectable level of EU capability-based actorness is qualified by two important realities, however: first, member state contributions to the Haiti quake were considerably more substantial than contributions from the EU itself, and second, more EU in-kind contributions (expertise, etc.) were delayed (relative to national contributions).

Consistency-related effectiveness: smooth and complementary relations in Brussels and in the field? The behaviour of EU member states and institutions in Brussels and in Haiti also illuminates the extent to which actor consistency was linked to effectiveness. With a collective decision being taken to launch a 'European response' to the disaster, EU institutions took a series of steps. On the Commission side, member state contributions were notified to other member states via the Monitoring and Information Centre (MIC). The Commission opened avenues for coordination between member states, various Commission DGs (including ECHO, Development and Humanitarian Aid and Relex ${ }^{46}$ ) and Haiti 
authorities (initially via the Haitian Embassy in Brussels). These actions had been planned and practised in recent years, not least to overcome coordination problems that came to light in the 2004 Asian Tsunami. ${ }^{47}$ Within 3 days of the earthquake, the MIC was coordinating (mainly in terms of linking requests with available capacities) among 17 participating EU member states. DG ECHO sent a team to Haiti on 14 March to assess needs and to initiate relations with other actors on the ground. ${ }^{48}$ While in the field, ECHO personnel reported back the necessary capabilities required and sought to avoid overlap and duplication among member states. The Commission's MIC was integrated into the United Nations' coordination structure and participated actively in the UN operations centre in Port-au-Prince. ${ }^{49}$

From the Council side, additional action was taken which, although adding to the EU's overall capabilities, probably detracted from its consistency. The Council's Joint Situation Centre (Sit Cen) established its own coordination unit (European Union Coordination Cell (EUCO)) in Brussels and a field office in Haiti to coordinate and exchange information among member states. Such coordination and information provision was focused on coordinating military resources, it should be added, and was deemed by one author to work effectively and smoothly. ${ }^{50}$ There were also regular inter-service coordination and interaction activities taking place within the Council Secretariat. ${ }^{51}$

To this response mix, we can add a role for the rotating Presidency of the Council. The Spanish Presidency took the lead in one critical area: the evacuation of roughly 2700 EU citizens from Haiti. That task was only partially completed by the end of January 2010, but the outcome was generally viewed favourably in terms of coordination and efficiency.

The last consistency question relevant to the effectiveness of the EU as an actor concerns the relationship between the EU and United Nations in the Haiti disaster. Several member states reported that confusion occasionally erupted regarding the interlinking of the EU and UN coordination units. Although the EU was part of the United Nations' coordination structure, individual member states were uncertain as to whether UN requests should be answered unilaterally or via the EU. This required extra coordination that, although smoothly carried out, took additional time that might have been better expended on other activities. ${ }^{52}$

It would seem, even after this relatively brief empirical overview, that the EU's lowlevels of actorness related to consistency-variables did not necessarily lead to less effectiveness. Coordination activities in Brussels and on-site in Haiti went relatively well with most member states participating in smooth processes. However, here too we can qualify these conclusions. Coordination via the EU was one type of coordination taking place in Haiti; while it went relatively well, EU coordination was only part of the larger response coordination effort in which EU member states took place. Nevertheless, even a partial assessment allows us to draw useful insights, which we return to in the conclusions, on the effectiveness of the EU in international disaster relief.

\section{United States}

Context-related effectiveness: quick recognition and acceptance of US role? As a major disaster relief provider, and as a widely recognised one, the United States should have been 
able to slip into a disaster relief role fairly easily following the Haiti earthquake. This was indeed the case, not least because of the United States' geographical proximity to the Caribbean and historical interest in the region. The United States is Haiti's largest external donor ${ }^{53}$ and is the home to a large Haitian population including 420,000 legal residents and illegal residents numbering in the range of 30,000 to $125,000{ }^{54}$ These ties ensured an almost 'automatic' acceptance of - and expectation for - a large US role. Large numbers of requests were immediately sent, and the US political establishment was fairly quickly engaged in the issue. From this perspective, a high degree of contextrelated actorness confirms our expectations of effectiveness: the United States had to waste no time convincing the global community or the local population that it had a major role to play. One aspect of effectiveness which links to context-related actorness is the rationale for taking part. To be sure, humanitarian concerns played a major role. But the possibility of massive refugee flows to the American mainland no doubt contributed to the rationale for action and led to some degree of suspicion regarding US efforts. ${ }^{55}$ Such criticism emerged not necessarily from Haitians but mainly foreign commentators (especially French) who were also concerned regarding the US reliance on military capabilities in the disaster response. ${ }^{56}$ Such criticism was largely a footnote to the case, however; we can generally say that a high degree of context-related actorness translated directly to swift and uncontroversial deployment in this case.

Coherence-related effectiveness: low transaction costs and clear leadership? Substantial interest coherence in the US response to the Haiti earthquake was indicated by the US President immediately taking a role. Barack Obama pledged to provide assistance to Haiti, stating that:

the people of Haiti will have the full support of the United States in the urgent effort to rescue those trapped beneath the rubble and to deliver the humanitarian relief of food, water and medicine that Haitians will need in the coming days. ${ }^{57}$

Secretary of State Hillary Clinton announced that the United States would provide military and civilian disaster assistance to affected families. ${ }^{58}$ Such statements, we might surmise, raised expectations and provided impetus behind the US response across the many different agencies being mobilised. It may have also provided broad political direction for agencies drawing up response plans.

In Washington, procedural coherence appears to have led to relatively efficient coordination. To promote coordination during the Haiti disaster, a cluster system, which organised the response into 12 clusters and 2 sub-clusters, was introduced. ${ }^{59}$ Efforts were also undertaken to ensure strategic coordination through the creation of the Coordination Support Committee (CSC), which brought together the US government, MINUSTAH, other donors and the humanitarian community and representatives of the US military. ${ }^{60}$ Pre-established procedures regarding military-civilian relations appear to have led to shared expectations regarding tasks and relatively smooth interaction (by historical standards, in any case). For example, the US military coordinated its activities with a host of other contributing nations through the UN cluster system. Nevertheless, criticism of the military focus in the US response, in contrast to civilian humanitarian assistance, resulted in a lack of leadership and coordination beyond the military response. ${ }^{61}$ 
Capability-related effectiveness: efficient mobilisation of the necessary resources? Most analysts, drawing upon a significant amount of empirical data, suggest the US response to the Haiti earthquake was fairly swift and well resourced. ${ }^{62}$ US Agency for International Development (USAID) provided an initial tranche of funds via the US Embassy in Port-au-Prince for the implementation of an instant emergency response programme. ${ }^{63}$ Within 24 hours of the earthquake, the United States began deploying search-and-rescue teams accompanied by support staff to Haiti. ${ }^{64}$ On 14 January 2010, President Obama announced that an additional US $\$ 100$ million would be provided in humanitarian assistance to help meet the immediate needs on the ground. Furthermore, USAID declared that it would provide some 14,550 tons of food aid (valued at approximately US\$18 million) to assist disaster victims. ${ }^{65}$ More than 250 medical personnel from the Department of Health and Human Services arrived early at the scene in Haiti, carrying two planeloads of medicines and supplies. The US Navy, via hospital ships, brought additional medical personal to Haiti.

Notable in the US mobilisation to Haiti was the military component. The US Southern Command (SOUTHCOM) led the cross-branch Joint Task Force-Haiti, which pulled together the military airlift response rather swiftly. 'Operation Unified Response' arrived at the scene within 24 hours after the earthquake to begin establishing logistical infrastructures. Within 3 days, 13,000 US troops had been deployed, which included 2200 Marines bearing heavy equipment to help clean debris-choked roads. On 21 January 2010, additional troops set out for Haiti to take part in the relief efforts, bringing the total number of US personnel involved to more than 16,000. At one point, the total deployment reached as high as 22,268. ${ }^{66}$ The US Air Force was involved, by way of the Air Mobility Command, in providing transport aircraft. In total, 264 military aircrafts were sent to Haiti. The US Navy deployed 23 ships to assist relief efforts, while the US Coast Guard (part of the Department of Homeland Security) provided 10 ships to assist with air-life evacuation of US civilians and performed investigative flights over Haiti to assess damage. ${ }^{67}$ By May, SOUTHCOM announced a troop drawdown, with roughly 1300 troops still in the field. ${ }^{68}$ Although the deployment of US military forces was generally successful, some problems with efficiency were also noted, especially because the effort lacked adequate military planning and sourcing and tracking, 'which created shortfalls in some areas'. ${ }^{69}$

By most accounts on the ground, the use of the military response by the United States to clear harbours, airports and roads was an important precondition for delivery of aid and assistance. In this sense, a high degree of actor capability led to an effective deployment of the most urgently required resources. There was criticism to be sure, including over-reliance on military hardware and US domination of harbour control and flight paths (which delayed some European flights ${ }^{70}$ ). From a disaster management perspective, however, such capabilities would seem critical for a disaster of the scale and magnitude of the Haiti quake.

The United States also moved rather swiftly (too swiftly, in the eyes of some ${ }^{71}$ ) towards post-disaster assistance. In April 2010, the US Department of State announced it would make additional contributions totalling US\$10.5 million to the United Nations High Commissioner for Refugees (UNHCR), the United Nations Children's Fund (UNICEF) and the Pan American Health Organization (PAHO). ${ }^{72}$ As of 7 May 2010, the 
total combined USAID and Department of Defense humanitarian assistance to Haiti amounted to over US\$ 1 billion. ${ }^{73}$ It has also been reported, however, that a large sum of this money has yet to be paid out. ${ }^{74}$

Consistency-related effectiveness: smooth and complementary relations in Washington and the field? The US response to the Haiti disaster was led by USAID. The US government set up an inter-agency task force to coordinate and facilitate humanitarian response through a Response Management Team (RMT) led by USAID and carried out by the Office of Foreign Disaster Assistance. ${ }^{75}$ But the military also played a critical role in responding to the disaster, particularly in the immediate aftermath of the earthquake by providing security, supplying medical services and delivering food. Other agencies involved in the response, as described above, included the US Coast Guard and the Department of Human Health and Services. Some commentators have drawn attention to the different priorities of various US agencies during the response. For instance, Moore argues that the efforts of the Coast Guard to prevent refugees from escaping Haiti undermined humanitarian efforts. ${ }^{76}$

In carrying out its humanitarian assistance to Haiti, the US Southern Command (SOUTHCOM) coordinated its efforts with the State Department and USAID. At an early stage of the relief effort, the US military helped to provide security for UN personnel in Haiti, supplied medical services and food to the Haitian people, took over certain critical government functions (such as control of the Port-au-Prince airport and maintenance of law and order), and attempted to improve the environment for international humanitarian work. ${ }^{77}$ Civil-military cooperation was also facilitated by the Humanitarian Assistance Coordination Center (HACC), set up by the Task Force-Haiti at the US Embassy in Port-au-Prince to integrate the military with other relevant stakeholders, including USAID and the United Nations. At the same time, US troops in Haiti were subject to controversy in some quarters. For example, a senior Italian official complained that the troops lacked adequate training in civilian relief operations and that there was a lack of civil-military cooperation on the ground in Haiti. ${ }^{78}$ Nevertheless, the US military response can be seen as fairly efficient and as a facilitator for humanitarian actors to carry out their work.

\section{Conclusion}

Both the EU and United States see a global role for themselves in international disaster relief. Assessing the extent to which either actor takes on the traits of 'actorness' as defined in the literature was just the starting point for this article. We went further than the traditional actorness literature by linking actorness characteristics to measures of effectiveness; we did so by drawing from other literatures and deriving plausible hypothetical expectations about those relationships. The case of the EU and US responses to the 2010 Haiti earthquake, with special focus placed on in situ behaviour, offered an opportunity to assess the validity of the relationships we posited between actorness and effectiveness. Although further research is required before anything resembling strong correlations can be established between actorness and effectiveness as proposed in this case, it is interesting to note a few suggestive findings from this study. 
First, for both the EU and United States, high degrees of context-related actorness seemed to ease each bloc's 'entry' into the disaster environment. Response from the local population and initial mobilisation efforts were largely positive. Second, for both the EU and United States, there seems to be a link between medium degrees of coherence-related actorness and a corresponding medium degree of transaction costs in the field. We saw instances of intra-organisational confusion and leadership contestation within the EU, but we also documented successes in coordination 'at home', which translated into success in the field.

Third, there seems to be a positive relationship between capability-related actorness and the ability to mobilise specific resources to the disaster site. For the EU, moderate levels of capabilities corresponded to moderate degrees of in situ success in mobilising and putting capabilities into action. This was the case even though access to critical infrastructure (harbours, airports and airspace) was largely unavailable, a set of circumstances that must be factored into the analysis. ${ }^{79}$

Finally, and somewhat curiously, the relationship between consistency-related indicators of actorness (which we described as 'follow through') and smooth ground coordination/division of labour between agencies is not particularly clear. For the EU, low degrees of consistency did not obviously lead to ineffectiveness (one explanation for this could be that the EU prefers channelling much of its assistance through NGOs already present on the ground); similarly, for the United States, moderate degrees of consistency had no obvious relationship to actual effectiveness of efforts. Such a result on this last indicator calls for more data collection to further explore the relationship and to verify our preliminary findings. It may also, and perhaps more importantly, require improved hypothesising about the relationship between actorness and effectiveness on this point.

Nevertheless, our analysis offers useful insights into both international disaster relief 'actorness' and links with actual effectiveness. Several aspects of the article deserve further attention in future analyses. One such aspect, as argued above, concerns data collection and the need to gather additional sources to further explore and understand critical nuances in the Haiti case. Another aspect concerns the proposed links between actorness and effectiveness. In addition to more refined theorising, it seems worthwhile to ask whether the hypotheses derived in this article might be applied more broadly, that is, in an area other than international disaster relief. A broader issue concerns the precise definition of effectiveness used. In this article, we define effectiveness in terms of 'goal attainment', which relates to policy effectiveness. However, goal attainment can take different forms using different metrics - a complication worth further exploring.

Finally, we note that the Haiti disaster took place just days after the establishment of the EEAS, an innovation of the Lisbon Treaty intended to unify and strengthen the EU's role in foreign affairs. However, the EEAS was not in operation at the time (this took 1 year of further planning and organisational reform) and had little operational effect on the EU's response. Although the Lisbon Treaty has few legal revisions to EU disaster cooperation per se, the more normative effects and cohering impact of the EEAS, and its head, the HR/VP, are deserving of further research. 


\section{Funding}

This research received no specific grant from any funding agency in the public, commercial, or not-for-profit sectors.

\section{Notes}

1. Arjen Boin, Magnus Ekengren and Mark Rhinard, 'The Study of Crisis Management', in Myriam D. Cavelty and Victor Mauer (eds.), The Routledge Companion of Security Studies (London: Routledge, 2010) pp: 452-62.

2. Stephen Krasner (ed.), International Regimes (Ithaca, NY: Cornell University Press, 1983).

3. Julia Steets and Daniel Hamilton (eds.), Humanitarian Assistance: Improving US-European Cooperation (Washington, DC: Center for Transatlantic Relations/Global Public Policy Institute, 2009); Nibedita S. Ray-Bennett, 'Environmental Disasters and Disastrous Policies: An Overview from India'. Social Policy and Administration, 41(4), 2007, pp. 419-24.

4. Erik Brattberg and Bengt Sundelius, 'Mobilizing for International Disaster Relief: Comparing US and EU Approaches to the 2010 Haiti Earthquake', Journal of Homeland Security and Emergency Management, 8(1), 2011 p. 1-13.

5. Gunnar Sjöstedt, The External Role of the European Community (Farnborough: Saxon House, 1997), p. 16.

6. Joseph Jupille and James A. Caporaso, 'States, Agency, and Rules: The European Union in Global Environmental Politics', in C. Rhodes (ed.), The European Union in the World Community (Boulder, CO: Lynne Rienner Publishers, 1998), p. 214.

7. Erik Brattberg and Mark Rhinard, 'The EU and US as International Actors in Disaster Relief', Bruges Political Research Papers, No. 22 (Bruges: College of Europe, January 2012).

8. The geographical proximity of Haiti to the United States appeared to make the latter a 'natural' respondent to the crisis in Haiti and to place unreasonable burdens on European ambitions to assist. In the event, however, both sides declared their resolve to assist. In fact, the United States occasionally appeared to balk in its response and European public expectations urging a strong, proactive role (not least because of the promises carried by the newly appointed High Representative/Vice President for foreign affairs at that time). Thus, Haiti allows for a comparative analysis despite geographical concerns.

9. Carol Cosgrove and Kenneth J. Twitchett (eds.), The New International Actors: The United Nations and the European Economic Community (London: Macmillan, 1970); Sjöstedt, The External Role of the European Community, p. 16.

10. Martin Holland, 'European Foreign Policy Transition in Theory and Practice', International Relations, 13(3), 1996, pp. 1-18.

11. Jupille and Caporaso, 'States, Agency, and Rules'.

12. Catherine Bretherton and John Vogler, The European Union as a Global Actor (Abingdon: Routledge, 1999 and 2005).

13. Jupille and Caporaso, 'States, Agency, and Rules'.

14. Bretherton and Vogler, The European Union as a Global Actor.

15. Daniel Thomas, 'Still Punching below Its Weight? Coherence and Effectiveness in European Union Foreign Policy', Journal of Common Market Studies, 50(3), 2012, pp. 457-73; Erik Brattberg and Mark Rhinard, 'The EU as an Emerging Actor in Global Counter-Terrorism', Forthcoming Special Issue edited by Laura C. Ferreira-Pereira and Bruno Olivera Martins in European Security (in press); also cf. Arne Niemann and Charlotte Bretherton, 'EU External Policy at the Crossroads: The Challenge of Actorness and Effectiveness', International Relations, 27(3), 2013, pp.261-275. 
16. Bretherton and Vogler, The European Union as a Global Actor; Martin L.P. Groenleer and Louise G. van Schaik, 'United We Stand? The European Union's International Actorness in the Cases of the International Criminal Court and the Kyoto Protocol', Journal of Common Market Studies, 45(5), 2007, pp. 969-98; for a fuller description, see Joachim A. Koops, The European Union as an Integrative Power? (Brussels: VUB Press, 2011), and the introduction to this issue.

17. Brattberg and Rhinard, 'The EU and US as International Actors in Disaster Relief'.

18. Arend Menon and Martin A. Schain, Comparative Federalism: The European Union and the United States in Comparative Perspective (Oxford: Oxford University Press, 2006).

19. Brattberg and Rhinard, 'The EU and US as International Actors in Disaster Relief'; Brattberg and Rhinard, 'The EU as an Emerging Actor in Global Counter-Terrorism'.

20. See introduction to this issue; Koops, The European Union as an Integrative Power?

21. See Roy H. Ginsberg, The European Union in International Politics: Baptism by Fire (Lanham, MD: Rowman \& Littlefield Publishers, 2001), p. 15.

22. Oran R. Young, International Governance: Protecting the Environment in a Stateless Society (Ithaca, NY: Cornell University Press, 1994).

23. cf. Katie V. Laatikainen and Karen E. Smith (eds.), The European Union at the United Nations: Intersecting Multilateralisms (Basingstoke: Palgrave Macmillan, 2006); Koops, The European Union as an Integrative Power; and the introduction to this issue.

24. Chhandasi Pandya, 'Private Authority and Disaster Relief: The Cases of Post-Tsunami Ache and Nias', Critical Asian Studies, 38(2), 2006, pp. 298-308; M. Stephenson, Jr., 'Making Humanitarian Relief Networks More Effective: Operational Coordination, Trust and Sense Making', Disasters, 29(4), 2006, pp. 337-50.

25. Michael Glance and Dale Jamieson, 'Societal Response to Hurricane Mitch and Intra- versus Intergenerational Equity Issues: Whose Norms Should Apply?', Risk Analysis, 20(6), 2000, pp. 869-82.

26. Nalini Suparamaniam and Sidney Dekker, 'Paradoxes of Power: The Separation of Knowledge and Authority in International Disaster Relief Work', Disaster Prevention and Management, 12(4), 2003, pp. 312-18.

27. cf. Arjen Boin, Paul 't Hart, Eric Stern and Bengt Sundelius, The Politics of Crisis Management: Publish Leadership under Pressure (Cambridge: Cambridge University Press, 2005).

28. Mark Rhinard and Bengt Sundelius, 'The Limits of Self-Resilience: International Cooperation as a Source of Resilience', in Louise K. Comfort, Arjen Boin and Chris C. Demchak (eds.), Designing Resilience: Preparing for Extreme Events (Pittsburgh, PA: University of Pittsburgh Press, 2010), pp. 196-219.

29. Boin, Hart, Stern and Sundelius, The Politics of Crisis Management.

30. Jeffrey Pressman and Aaron Wildavsky, Implementation (Los Angeles, CA: University of California Press, 1973).

31. Brattberg and Rhinard, 'The EU and US as International Actors in Disaster Relief'.

32. For a helpful summary of the Haiti earthquake and its effects, see Marc O. Eberhard, Steven Baldridge, Justin Marshall, Walter Mooney and Glenn J. Rix, 'The $M_{W} 7.0$ Haiti earthquake of January 12, 2010' (US Geological Survey, 2010).

33. The country became independent from France after an uprising in 1804, and French remains the official language of this Caribbean nation.

34. 'France's Sarkozy Visits Earthquake-Ravaged, Haiti', BBC News, 17 February 2010.

35. European Council, 'Council Conclusions on the Earthquake in Haiti' (Brussels: European Council, 18 January 2010).

36. See, for example, 'EU Struggles to "fly the flag" in Haiti', EurActiv, 25 January 2010. 
37. 'Lady Ashton under Fire Over "EU visibility", Telegraph, 22 January 2010; 'La diplomate en chef de l'UE, critiquée pour sa gestion de crise', Le Point, 19 January 2010.

38. Interviews, Brussels, May 2010.

39. EU Commission, 'EU Fact Sheets on Haiti', 28 January 2010, available at: http://europa.eu/ $\mathrm{rapid} /$ pressReleasesAction.do?reference $=\mathrm{MEMO} / 10 / 22 \&$ format $=$ HTML\&aged $=0 \&$ languag $\mathrm{e}=$ EN\&guiLanguage $=$ en\#footnote-8 (accessed 19 June 2012).

40. European Council, 'EU Security and Defense News', Issue 1 (Brussels: European Council, 1-11 March 2010), available at: http:/www.consilium.europa.eu/uedocs/cms_data/docs/ pressdata/en/esdp/113312.pdf (accessed 19 June 2012).

41. This sum comprises the pledges of 18 member states, the Commission and the European Investment Bank; from this sum, the European Commission pledged $€ 460$ million. European Commission, 'Haiti', 17 February 2012, available at: http:/ec.europa.eu/europeaid/where/ acp/country-cooperation/haiti/haiti_en.htm (accessed 19 June 2012).

42. European Commission, 'The EU Civil Protection Mechanism Intervention in Haiti', MEMO/10/7 (Brussels: European Commission, 19 January 2010).

43. The European Gendarmerie Force (EGF) is an initiative of six member states (France, Italy, Romania, Spain and the Netherlands). The idea behind the EGF cooperation is to allow a fast deployment (within 30 days) of interoperable EU police forces carrying military status.

44. Ambitions for joint military EU contributions were high at this stage. In a written statement on February 11, Catherine Ashton even spoke of her intention to propose 'an EU military mission'. 'EU Eyes Military Mission to Help Haiti Quake Victims', EU Business, 11 February 2010.

45. Pol Morillas, 'Institutionalization or Intergovernmental Decision-Taking in Foreign Policy: The Implementation of the Lisbon Treaty', in Paul J. Cardwell (ed.), EU External Relations in the Post-Lisbon Era (The Hague: Springer, 2012), p. 131.

46. The Commission's Directorate for External Relations has subsequently ceased to exist, with many of its responsibilities having been transferred into the new European External Action Service.

47. See Antonio Missiroli, 'Disasters Past and Present: New Challenges for the EU', Journal of European Integration, 28(5), 2006, pp. 423-36; Magnus Ekengren, Nina Matzén, Mark Rhinard and Monica Svantesson, 'Solidarity or Sovereignty? EU Cooperation in Civil Protection', Journal of European Integration, 28(5), 2006, pp. 457-76.

48. EU Delegation to the US, 'EU Focus Newsletter: EU Emergency Assistance: Humanitarian Aid and Disaster Response', May 2010, available at: http://www.eurunion.org/eu/images/ eufocus-humaid-may2010.pdf (accessed 19 June 2012).

49. Delegation of the EU to the United Nations, 'Haiti: The Civil Protection Mechanism in Haiti', 20 January 2010, available at: http://www.eu-un.europa.eu/articles/fr/article_9423_fr.htm (accessed 19 June 2011).

50. Giji Gya, 'Breaking the EU silos in CFSP - An Organisational Change Professional Needed', ISIS Europe, May 2010, available at: http://isis-europe.eu/sites/default/files/programmesdownloads/2010_artrel_488_esr49-breaking-silos.pdf (accessed 19 June 2012).

51. Arjen Boin, Magnus Ekengren and Mark Rhinard (2013) The European Union as a Crisis Manager: Patterns and Prospects. Cambridge: Cambridge University Press.

52. For a helpful discussion about the EU's cooperation with the United Nations during the Haiti earthquake relief efforts, see Claudia Morsut, 'The European Union - United Nations Co-operation in Aid, Relief and Reconstruction. The Haiti Case' (paper presented at the Third Global International Studies Conference, Porto, Portugal, 17-20 August 2011).

53. 'Haiti Military Guide', GlobalSecurity, available at: http://www.globalsecurity.org/military/ world/haiti/poverty.htm (accessed 19 June 2012).

54. 'The Long History of Troubled Ties between Haiti and the United States', BBC News, 16 January 2010. 
55. Annica Moore, 'Catastrophe and Containment: A Critical Analysis of the US Response to the 2010 Haiti Earthquake' (paper presented at The Third Global International Studies Conference, Porto, Portugal, 17-20 August 2011).

56. 'US Accused of “occupying” Haiti as Troops Flood in', Telegraph, 18 January 2010.

57. White House, 'Remarks by the President on Rescue Efforts in Haiti' (Washington, DC: White House, 13 January 2010), available at: http:/www.whitehouse.gov/the-press-office/remarkspresident-rescue-efforts-haiti (accessed 19 June 2012).

58. US Department of State, 'Remarks by the Secretary of State on the Situation on Haiti' (Washington, DC: US Department of State, 13 January 2010), available at: http://www.state. gov/secretary/rm/2010/01/135144.htm (accessed 19 June 2012).

59. In the field, the humanitarian community was provided support from Office for the Coordination of Humanitarian Affairs (OCHA) on inter-cluster coordination, information management and analysis, mapping, civil-military liaison, donor coordination, advocacy and media outreach.

60. Inter-Agency Standing Committee, 'Response to the Humanitarian Crisis in Haiti: Achievements, Challenges and Lessons to Be Learned' (July 2010). See also Paul E. Weisenfeld, 'Successes and Challenges of the Haiti Earthquake Response: The Experience of USAID’, Emory International Law Review, 25(3), 2011, pp. 1097-120.

61. This argument was, for instance, made by the head of Italy's civilian protection agency, Guido Bertolaso, in the aftermath of the earthquake. 'Italian Official Condemns Haiti Earthquake Relief as "vanity parade", The Guardian, 25 January 2010.

62. See, for example, François A. Grünewald, Andrea Binder and Yvio Georges, 'Inter-Agency Real Time Evaluation in Haiti: 3 Months after the Earthquake' (Final Report, Groupe URD and GPPi, 31 August 2010); International Crisis Group, 'Haiti: Stabilisation and Reconstruction after the Quake', Latin America/Caribbean Report No. 32 (31 March 2010), available at: http://www.crisisgroup.org/en/regions/latinamerica-caribbean/haiti/032-haiti-stabilisationand-reconstruction-after-the-quake.aspx (accessed 19 June 2012); Nicole Rencoret, Abby Stoddard, Katherine Haver, Glyn Taylor and Paul Harvey, 'Haiti Earthquake Response: Context Analysis' (ALNAP and UNEG, July 2010), p. 22, available at: http://www.alnap.org/ pool/files/haiti-context-analysis-final.pdf (accessed 19 June 2012).

63. USAID, 'Factsheet Number 1 Haiti earthquake' (Washington, DC: USAID, 13 January 2010), available at: https://www.cimicweb.org/cmo/haiti/Crisis\%20Documents/USAID-OFDA\%20 Situation\%20Reports/02.16.10-USAID-DCHAHaitiEarthquakeFactSheet35.pdf (accessed 19 June 2012).

64. The US also already had a search and rescue team on the ground in Haiti at the time of the earthquake that could begin operations immediately.

65. USAID, 'USAID to Provide Emergency Food Aid for Haiti Earthquake Victims' (Washington, DC: USAID, 13 January 2010), available at: http://www.usaid.gov/news-information/pressreleases/usaid-provide-emergency-food-aid-haiti-earthquake-victims (accessed 19 June 2012).

66. US Southern Command, 'Narrative History of Operation Unified Response' (Washington, DC: DOD, 1 November 2010), available at: http://www.southcom.mil/newsroom/Pages/OperationUnified-Response-Support-to-Haiti-Earthquake-Relief-2010.aspx (accessed 19 June 2012).

67. US Southern Command, 'Narrative History of Operation Unified Response' (Washington, DC: DOD, 1 November 2010).

68. 'US Military Operation in Haiti Draws to Close', Boston Globe, 19 April 2010.

69. P.K. Keen, Matthew G. Elledge, Charles W. Nolan and Jennifer L. Kimmey, 'Foreign Disaster Response: Joint Task Force-Haiti Observations', Military Review, 90(6), 2010, p. 87.

70. 'US Opens Airport to More Humanitarian Flights', Inter Press Service, 19 January 2010.

71. See 'US Mulls Role in Haiti after Crisis', The New York Times, 17 January 2010. 
72. US Department of State, 'Department of State Announces \$10.5 Million Contribution to Address Migration-Related Challenges in Aftermath of Haiti Earthquake', 29 April 2010, available at: http://www.state.gov/r/pa/prs/ps/2010/04/141033.htm (accessed 19 January 2012).

73. USAID, 'Factsheet Number 53 - Haiti Earthquake', 7 May 2010, available at: http://reliefweb. int/sites/reliefweb.int/files/resources/F49AFEF0F27D3DD84925771D0001D069-Full_ Report.pdf (accessed 19 January 2012).

74. 'Funding Delays, Housing Complexities Slow Haiti Rebuilding Effort', The Washington Post, 25 November 2010.

75. Rhoda Margesson and Maureen Taft-Morales, 'Haiti Earthquake: Crisis and Response' (Washington, DC: Congressional Research Service, 19 February 2010).

76. Moore, 'Catastrophe and Containment'.

77. For a field account of the kind of support provided by the US military to medical personnel present on Haiti after the earthquake, see Paul S. Auerbach, Robert L. Norris, Anil S. Menon, Ian P. Brown, Solomon Kuah, Jennifer Schwieger, Jeffrey Kinyon, Trina N. Helderman and Lynn Lawry., 'Civil-Military Collaboration in the Initial Medical Response to the Earthquake in Haiti', New England Journal of Medicine, 362, 11 March 2010, p. 32.

78. 'Haiti Relief Lacks Leadership, Says Italian Expert', BBC News, 25 January, 2010. A study conducted by the US Government Accountability Office (GAO) also found some shortcomings in SOUTHCOM's collaboration with other government partners. US Government Accountability Office, 'US Southern Command Demonstrates Interagency Collaboration, but Its Haiti Disaster Response Revealed Challenges Conducting a Large Military Operation' (Washington, DC: GAO, July 2010).

79. At the same time, the causality between capability and ability to mobilise specific resources to a disaster site need to take into account situations where opportunities for deployment are denied. Even if the EU would have been able to mobilise capabilities effectively, the ability to deliver them could be limited in a situation where access to critical infrastructure, such as harbours, airports and airspace, is unavailable.

\section{Author biography}

Erik Brattberg is a Research Associate at the Swedish Institute of International Affairs and a Visiting Fellow at the Center for Transatlantic Relations at the Paul H. Nitze School of Advanced International Studies (SAIS) at Johns Hopkins University. He has previously published on European foreign policy and European Union-United States relations in European Security, Journal of Crisis Management and Civil Contingencies and Journal of Homeland Security and Emergency Management.

Mark Rhinard is Associate Professor at Stockholm University and a Senior Research Fellow at the Swedish Institute of International Affairs. He is also a Senior Advisor to the European Policy Centre in Brussels and previously taught at Cambridge, Oxford and Leiden universities. His research interests include European Union integration trends, cooperation on crisis management questions and institutional design. His latest book is titled The European Union as Crisis Manager: Problems and Prospects (Cambridge University Press, 2013). 